Nataliia Pavlova, PhD (Pedagogy), Ass. Prof. Rivne State University for the Humanities, Rivne, Ukraine

\title{
TASK APPROACH IN THE SYSTEM OF METHODICAL TRAINING OF INFORMATICS TEACHERS
}

\begin{abstract}
The classifications of pedagogical tasks are analyzed, and revealed the peculiarities of their use in the system of methodical training of future teachers. The methodical task in which the pedagogical situation in the plane of studying of a subject is modeled is allocated. The expediency of professional training of future computer science teachers with the use of educational and methodical tasks at all stages of higher education is substantiated, examples of such tasks are considered and the stages of their solution are generalized.

Keywords: computer science teacher, student, educational and methodical task.
\end{abstract}

Introduction. The development of modern society and high requirements for the qualification of "teacher" lead to the modernization of the system of methodological training of teachers in higher education institutions (HEI). The main task of higher education is the acquisition of competencies by future teachers through mastering the fundamental knowledge, the development of creative techniques, the formation of different styles of thinking and professional values of personality. As students can gain initial experience in the specialty through active learning activities, balanced study of methodological achievements of the teaching community and generating knowledge in specific working conditions that correspond to today, the importance of the practical component in the process of higher education is extremely high.

Therefore, it is appropriate to build bachelors' and masters' training who receive higher education in the specialty 014 Secondary education (computer science) using a problem-based approach that outlines the forms, methods and techniques, also taking into account the subject-methodological direction of professional development of teachers future work. The logic of the deployment of the problem approach is determined by the educational goals, the processes of formation and development of general and professional competencies.

The purpose of the article. The aim of the article is to study the peculiarities of using in the system of methodical training of teachers the problem approach, such as educational and methodical tasks on the methods of teaching computer science, based on the professional context. To achieve this goal the following tasks were set: to reveal the relevance of professional training of future teachers using the task approach, to investigate the classification of pedagogical tasks, to describe the interpretation of the concept of "methodical task" and to characterize the content of educational tasks in the system of teacher training; give examples of educational and methodical tasks on methods of teaching computer science.

Research methods. This research was conducted using the following methods: analysis and synthesis of scientific information in the psychological, pedagogical and educational literature; selection of the main and systematization in order to classify key concepts; generalization - to formulate conclusions; diagnostic concept (questionnaires, discussions) - in order to study the practical component of the research.

Recent research and publications analysis. In the works of such scientists as G. O. Ball, O. V. Bezpalko, V. V. Davydov, G. S. Kostyuk, O. M. Leontiev, Y.I. Mashbyts laid the foundations for understanding the problem as an interdisciplinary phenomenon. Different approaches to the classification of educational problems are analyzed in the works of D. M. Bogoyavlensky, Y. M. Kulyutkin, I. Y. Lerner,
M. I. Mahmutov, V. A. Slastyonin and others. The use of pedagogical tasks in the educational process in $\mathrm{HEI}$ was studied by O.P. Demchenko, O. A. Dubaseniuk, N. O. Dyachenko, I. A. Zyazyun, R. P. Karpyuk, V. A. Kovalchuk, L. V. Kramushchenko, N. V. Kuzmina, A .l. Kuzminsky, A. H. Kurashinova, O. V. Matvienko, I. V. Novitskaya, O. M. Polyakova, L. F. Spirin, L. M. Friedman, M. L. Frumkin and others. Features of application of methodical tasks in the system of methodical preparation of future teachers were studied by I. A. Akulenko, N. A. Igna, V. I. Kovtunova, N. V. Mayer, L. O. Milto, I. I. Osadchenko, S. O. Skvortsova and others. At the same time, the issues of professional training of future computer science teachers using a problem-based approach, such as solving educational and methodological problems, are topical and not fully learned.

Presentation of the main positions. The task is the purpose of the activity of the individual, which is formulated in specific conditions and to solve which you need to apply a known or invent a new course of action. In the dictionary source, a professional task is described as a task that is aimed at "performing the problem (problems), which is set to the specialist as a professional" [Slovnyk-dovidnyk, 2006, p. 71-72). This task is modeled in different ways, but the peculiarity of achieving the requirements (goals) formulated in it is determined by the set of competencies possessed by the specialist, his readiness to qualify for professional duties.

It is expedient to describe and project the professional activity of teachers through a system of pedagogical tasks, which differ from others in that the content of each of them is not set in a ready form, and the method of solving is essentially a creative solution. The activity component of the pedagogical process "contains the interaction of teachers and students, their cooperation, organization and management of the process to achieve the end result, methods, tools and forms of interaction" [Slovnyk-dovidnyk, 2006, p. 134].

Pedagogical tasks that are used at all stages of students' qualification "teacher", but with different didactic purposes (for example, demonstrate the way of solving, form the skill of professional communication, develop pedagogical analysis) and in a certain organized didactic learning environment (for example, classroom and extracurricular work) are cognitive tasks that put students in a position of incomplete knowledge in relation to the requirements and the elimination of such contradictions is based on the students skill possibilities. Finding a way out of difficulties and achieving the goal is a process of solving the problem.

The analysis of scientific and methodological literature showed the existence of a number of classifications of pedagogical tasks, each of which summarizes the individual criteria of grouping, not contradicting each other, but describing the phenomenon from a certain angle (Table 1). 
Pedagogical tasks characteristics

Table 1

\begin{tabular}{|l|l|}
\hline \multicolumn{1}{|c|}{ Researcher } & \multicolumn{1}{c|}{ Signs (features) of pedagogical tasks classification } \\
\hline I. V. Novitska & - nature of occurrence (predicted, operational, typical, atypical); \\
[Novitska, 2015, p. 62] & $\begin{array}{l}\text { activity of the teacher); } \\
\text { - learning functions (purpose of students' cognitive activity, search for information support of activity within } \\
\text { the discipline, etc.); } \\
\\
- \text { learning content (motivational, strategic, etc.). }\end{array}$ \\
\hline N. O. Dyachenko & - cognition of the essential features of pedagogical concepts and processes (knowledge); \\
& - identification of flexibility of thinking and pedagogical knowledge (understanding); \\
[Dyachenko, 2015, p. 26] & - planning of professional activity, finding the means and methods of its implementation (application); \\
& - forecasting results (analysis); \\
& - application of various tools and methods of teaching (synthesis); \\
& - assessment of the correctness of pedagogical actions, learning outcomes (assessment).
\end{tabular}

An aspect of pedagogical tasks is a methodical task, which simulates the pedagogical situation in the field of studying in a secondary education institution (SEI) of a particular subject, which contains requirements for understanding and practical use of general scientific, subject and psychological-pedagogical knowledge and skills, and also knowledgeability of the methodology of teaching the subject. The concept of "methodical task" in the study of the system of methodical training of teachers is common and contains descriptions from the representation of its structural element in the content of education to the identification with the didactic tool in the technology of knowledge acquisition.

V. I. Kovtunova interprets the methodological task from two positions: as a task of professional activity of the teacher, which reflects the organization of the learning process in the subject; as a means of teaching students, the use of which is aimed at the formation of relevant knowledge and skills [Kovtunova, 2006, p. 9-10].

Some ways of application of situational and methodological tasks as a didactic tool were the subject of research by L. A. Chernysheva [Chernysheva, 2017, p. 50]. Describing the practice-oriented problem situation, the scientist focused on information-analytical, analyticalsynthetic, design, organizational-preparatory, operationalpractical methodological tasks, in each of which she singled out: situation-illustration (demonstrates mechanisms, consequences); situation-problem (demonstrates the search for a solution); situation-assessment (provides a critical analysis of the chosen method of solution, the decision); situation-exercise (requires processing of special sources of information).

Close to the above descriptions are the explanations of O. I. Ivanitsky that explain the methodological task as "a model of a specific situation, the solution of which involves the simulation of the educational process in conditions as close as possible to real" [lvanitsky, 2014, p. 269]. This task can have several solutions, taking into account the individual characteristics of both the learner and the teacher. The content of the methodological task should correspond to the level of knowledge and activity readiness of students to solve it, provide for the application of subject knowledge and technological skills in specific conditions, reconcile personal and professional values, motivate students to selfdevelopment as a future teacher.

Valuable for our study is the definition of "methodical modeling" used by I. A. Akulenko, the content of which the scientist describes as follows: it is the process of construction and study of methodological objects, as well as their operation; in turn, the concept of "methodical object" combines all the elements that form the methodology of teaching the subject as a science and as a discipline in the HEI [Akulenko, 2013, p. 294-295]. Methodical modeling involves the transformation of a methodical object or its model according to specific conditions of use. Methodical objects used in modeling and in setting other types of pedagogical tasks are: goals and content of education; didactic teaching tools (methods, techniques, tools and forms of organization); control and correction of students' academic achievements, etc. Methodical modeling synthesizes the following phases: adaptation (awareness of the need to build a model, the allocation of an indicative basis for action); situational-search (assimilation of methodical knowledge, their generalization and systematization); integrative-reflexive (formation of didacticmethodical developments and their transfer to the practical plane for the purpose of formation of own style in a profession, realization of the program of professional development).

According to M. M. Nesterenko, "modeling provides the implementation of the teacher's skills to analyze, plan, predict, construct, because it is based on the ability of thinking to establish analogies in the abstract comparison of different objects" [Nesterenko, 2019, p. 27]. Thus, the lesson modeling is an artificially created fragment of the interdependent activity of the teacher (pedagogical management, teaching) and educational and cognitive activities of students (learning), focusing on their constant connection, as well as the transfer of learned behaviors into similar to the teaching profession. The development of students' ability to model a lesson is conditioned by the development of skills to plan the interaction of all participants in the educational process, select visual support, formulate the purpose of the lesson, realizing its place in the system, analyze the effectiveness of pedagogical design.

Based on the fact that the methodological task requires understanding, design and implementation of pedagogical actions, it is advisable to use in the description of the practical component of professional training of future teachers the concept of "educational and methodological task". It is characterized primarily by the specification of the educational task, which is designed to teach students and purposeful formation of methodological competence, which is interpreted as a result of methodological training, which is reflected in the ability to effectively perform methodological activities in organizing the process of teaching computer science in SEI. This task encourages students to realize the importance of knowledge of the methods of teaching the subject, to transform and synthesize them, to form balanced pedagogical decisions, to plan activities and predict the consequences of its implementation.

G. V. Monastyrna uses the term "educational pedagogical task" and believes that the formulation of the task in the form of "Identify the problem in the given situation and suggest ways to solve it" motivates future computer science teachers to describe their actions, integrate knowledge and skills from different fields into practical 
experience, to work out certain behavioral reactions [Monastyrna, 2009, p. 88]. The use of such a task requires specially organized learning, in which attention is focused on pre-selected and clearly defined known or unknown, standard or unique learning situations that are practically significant for students.

The content of each educational and methodical task is built around questions, the search for answers to which ambiguous solution, is not algorithmic and depends on many aspects, and also taking into account the peculiarities of educational material. Other characteristics of the tasks include: problemsolving, which results in the acquisition of new knowledge; relevance, which is achieved by reflecting the holistic context of the computer science teacher's professional duties. It is equally important to develop students' desire to use modern educational technologies and innovative teaching methods in their activities. It should be noted that a significant part of such skills is formed in students during laboratory-practical work, individual research projects of different content and level of complexity in classroom and extracurricular work, based on the linear-concentric structure of the school curriculum of computer science because:

- individual parts of the educational material in a linear structure form a continuous sequence of interconnected links, and new knowledge is built on the basis of previously acquired knowledge and are in close connection with them;

- the study of basic units in a concentric structure occurs several times, but with elements of complication and expansion with new features, deepening of connections and dependencies between them.

To master the current trends in methods of teaching computer science, we suggest that when studying the discipline "Methods of teaching computer science" to use educational and methodological tasks with mandatory discussion and modeling of decisions. The main requirement for the use of educational and methodological tasks is that the described situation corresponds to a specific educational topic, focused on the productive and creative activities of students in the information and communication pedagogical environment. The success of solving such problems is determined by the ability to persistently study scientific and methodological literature and school textbooks, the activity and initiative of all participants in the educational process. In order to master the general and special (study of individual sections, topics, concepts) methods of teaching computer science, we offer students to solve educational and methodological problems:

- analytical (diagnostics of the level of development of students in order to effectively manage the learning process; study of technological solutions, etc.);

- constructive (selection of educational material; formulation of students' methods of activity; choice of teaching methods, etc.);

- creative (synthesis of knowledge from different fields, transfer of own experience from one condition to another, search of ways of realization of innovative ideas of training);

- reflexive (forecasting the prospects of developing their own style in the profession; the formation of ways to adjust their own activities, etc.).

Educational and methodical tasks can be classified according to various criteria, including: the specifics of the content of educational material; way to achieve the result; the level of complexity of the solution; the nature of mental activity. Among the criteria for the classification of educational and methodological tasks identified by N. V. Mayer are: purpose (formation and development of methodological skills); self-standing of methodical decisions (analytical; modeling; creative); use of information and communication technologies (ICT) [Majyer, 2016, p. 26].
Here are fragments of educational and methodical tasks that students were asked to solve during the development of methods of studying the section "Data encoding and computer hardware":

1) formulate the didactic purpose of one of the lessons in the 8th grade and place the document on Google Drive, giving access to classmates; comment on the purpose of the lesson, formulated by a classmate;

2 ) in the presented synopsis of the lesson find methodological errors and eliminate them, justifying the decision; supplement the lesson outline with didactic works (file-blank, demonstration video, presentation, test) and place the materials in Google Classroom;

3) make a selection of electronic educational resources for in-depth study of this section; develop a three-level scale for evaluating Internet resources; present the result in the form of a table: name and address of the resource; content; keywords (in English); evaluation of work with the resource on the developed scale;

4) select the techniques and teaching methods that can be used by the teacher after he described the next stage of the lesson as follows: "let's move on to the study of units of measurement of the length of the binary code";

5) give examples of multilevel questions, the answers to which require the use of interdisciplinary links;

6) compare the presentation of educational material on the topic "Binary coding. Units of measurement of the length of the binary code "in two different textbooks, developing a detailed plan for each paragraph (display the results in the form of notes or a map of knowledge);

7) develop infographics in order to increase students' interest in studying this section;

8) perform the practical work "Configuring a computer as needed" according to the instructions in two different textbooks for 8th grade, complete the performance report with information about the configuration and cost: a computer for games and entertainment; a mobile phone for communication of a family member; laptop for eighth grader learning.

To achieve the goal of the publication, a questionnaire was conducted in which 4th year students who completed the study of methods of teaching computer science had to identify the most important for them types of methodical activities of teachers (Fig. 1), indicate those activities that caused difficulties during their modeling in educational and methodical tasks (Fig. 2).

The answers to the first question were as follows:

- $73 \%$ of respondents noted the importance of determining methods and techniques of teaching in accordance with the stated objectives of the lesson, as well as the development of different types of computer science lessons based on various learning technologies;

- more than $40 \%$ of students focused on the balanced use of ICT and teaching methods to develop motivation for learning and cognitive activity of students;

- $39 \%$ of students emphasized the prediction of learning outcomes and problem situations when studying the topic;

- more than half of the respondents chose the forms and methods of diagnosing students' academic achievements.

Answering the second question, $73 \%$ of students emphasized the difficulties in programming and algorithmization, $50 \%$ of respondents had complications in which they had to analyze the lesson, identify methodological shortcomings and suggest their own solution. According to $27 \%$ of students, significant efforts required the following tasks: to develop outlines of different types of lessons and model them in practice; develop didactic material, demonstrate mastery of ICT skills as a learning tool. 


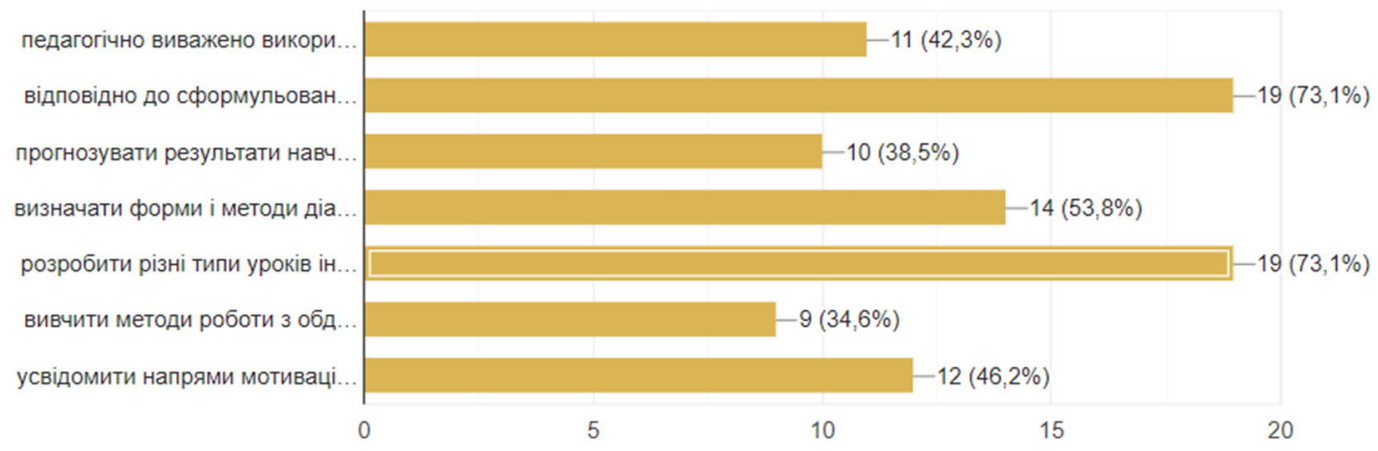

Fig. 1. The result of a survey of students

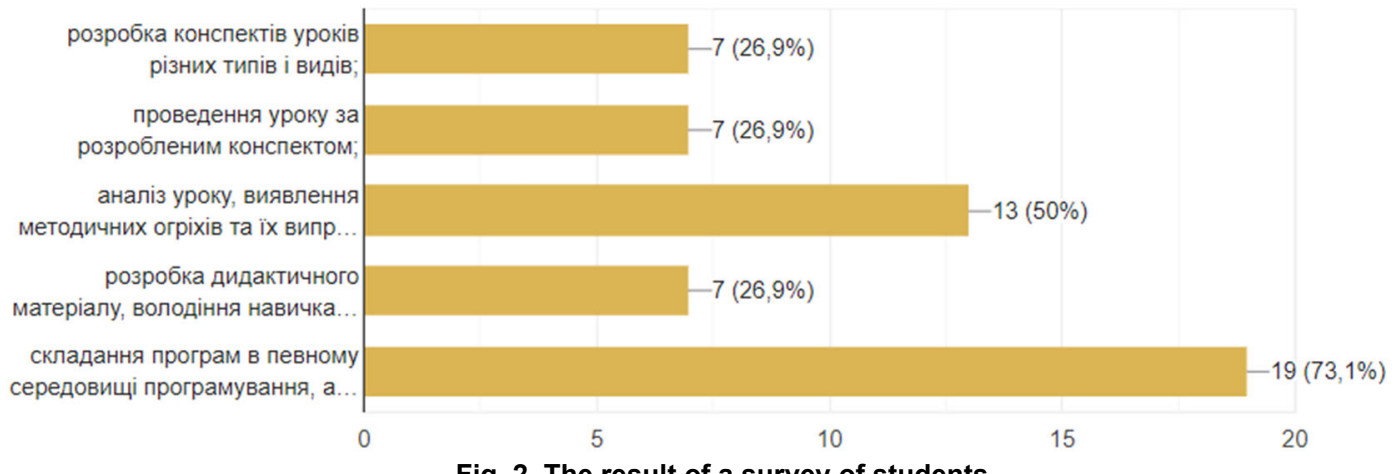

Fig. 2. The result of a survey of students

Practice shows that within the course "Methods of teaching computer science" the result is a prepared lesson outline or methodological development on a particular topic with the necessary supporting materials of varying difficulty, which allows to take into account the level of preparedness of students. The process of solving problems has its own characteristics and consists of stages, which in the general scheme can be represented as follows:

- analysis of the condition (separation of contradictions; establishing causal links between the condition and the requirement);

- mobilization of necessary knowledge and experience to determine ways to solve;

- selection of the most effective way of solving and its implementation;

- analysis of the solution process and the results obtained by the teacher and students.

Generalizations of the above theoretical and practical aspects give grounds to assert that educational and methodical tasks, combining the process of student learning and future pedagogical activities, perform motivational, educational, diagnostic, developmental functions. The motivational function aims to expand interest in the study of teaching methods as a science and a source of development of professionally significant personal qualities. The educational function is realized by using tasks as educational and didactic material to study the content of the school course of informatics, analysis from the standpoint of fundamental informatics and principles of technological learning, as well as developing methods and techniques of methodical activity, integrating psychological, pedagogical, subject and methodological knowledge. The diagnostic function aims to determine the level of knowledge, skills and abilities, the formation of methodological competence of the subject. The developmental function lies in the development of professionally important personal qualities, professional thinking and characteristics such as flexibility, critical thinking, personality effectiveness.

Educational and professional direction on the one hand, the presence of elements of creativity, independence - on the other, allow us to consider the task approach both as a method and as a means of collective, group and individual learning of students in the system of methodological training in $\mathrm{HEI}$. Areas of coverage of higher pedagogical education with task technology are determined by the professional responsibilities of teachers and the peculiarities of his methodological activities in SEI, the content of educational and professional program for which students obtain the qualification of "teacher" and a number of other regulations. The ability to solve problems is an important criteria for the formation of professional competencies, including methodological competence of future teachers in the HEI.

Conclusions and prospects of further research. The use of a problem-based approach aimed at the formation of students' professional competencies implements the concept of a balanced combination of traditional learning with practical and innovative technologies. Analysis of scientific and methodological sources allows us to conclude that there is no single interpretation of the peculiarities of the use of the problem approach in the high educational institutions. Also, today there is no established scientifically based classification of pedagogical tasks, which in various ways reflects the originality of the teacher's methodological activities. This situation allows us to consider tasks as a means of professional training of future teachers and as a method of teaching, the characteristic features of which are the organization and management of educational and cognitive activities, when each student takes an active position and forms a personal attitude to solving contradictions.

Educational and methodical tasks form in the educational process a kind of tasks that model pedagogical activity, mastering methodical techniques, methods and techniques of teaching and learning a specific subject. The educational and methodological task we understand as a pedagogical situation, which integrates the main elements of the teacher's methodological activities and which creates conditions for planning, forecasting, design and management of the educational process by the teacher and the implementation of appropriate educational and cognitive actions by the student. 
Prospects for further research are to determine the levels of formation of methodological competence of future teachers and enhance their effectiveness by solving a variety of educational and methodological tasks in all forms of organization of the educational process in $\mathrm{HEI}$ to increase the competitiveness of higher education in the modern labor market.

References

Slovnyk-dovidnyk z profesijnoyi pidhotovky / Za red. A. V. Semenovoyi. Odesa: Palmira, 2006. $221 \mathrm{~s}$.

Novitska I. V. Formuvannya profesijnyx umin majbutnix uchyteliv pryrodnycho-matematychnyx dyscyplin u procesi rozvyazuvannya pedahohichnyx zadach: dys. ... kand. ped. nauk: 13.00.04 / Zhytomyrsky] derzhavnyj humanitarnyj universytet im. I. Franka, Zhytomyr, 2015. $198 \mathrm{~s}$.

Dyachenko N. O. Formuvannya vmin rozvyazuvaty pedahohichni zadachi u majbutnix vykladachiv pedahohiky na mahisterskomu rivni: dys. ... kand. ped. nauk: 13.00.04 / Nacionalna akademiya pedahohichnyx nauk. Instytut vyshhoyi osvity, Kyiv, 2015. 189 s.

Chernysheva L.A. Metodika podgotovki budushhih uchitelej himii posredstvom reshenija situacionno-metodicheskih zadach $v$ uslovijah pedagogicheskoj praktiki: dis. ... kand. ped. nauk: 13.00.02 / Brjanskij gosudarstvennyj universitet im. akad. I. G. Petrovskogo, Brjansk, 2017. 189 s.

Kovtunova T. I. Metodicheskie zadachi v predmetnoj podgotovke uchitelja matematiki: avtoref... kand. ped. nauk: 13.00.02. Orel. 2006. 20 s.

Ivanitsky O. I. Metodychni zavdannya yak efektyvnyj zasib formuvannya metodychnoyi kompetentnosti majbutnix uchyteliv fizyky. Zbirnyk naukovyx prac Kamyanec-Podilskoho nacionalnoho universytetu im. I. Ohiyenko, 2014. Vyp. 20. S. 268-271.

Akulenko Y.A. Metodycheskye modely kak obъektы usvoэnyya $v$ processe metodycheskoj pidhotovky budushhoho uchytelya matematyky profylnoj shkolы. Vektor nauky THU. 2013. № 1 (23), S.293-297.

Nesterenko M. M. Pidhotovka majbutnix uchyteliv do modelyuvannya uroku $v$ umovax variatyvnosti pochatkovoyi osvity: dys. .... kand. ped. nauk: 13.00.04 / Berdyanskyj derzhavnyj pedahohichnyj universytet. Berdyansk, 2019. $249 \mathrm{~s}$.

Monastyrna H. V. Formuvannya profesijnoyi kompetentnosti majbutnix uchyteliv informatyky zasobamy informacijno-pedahohichnoho modelyuvannya: dys.... kand. ped. nauk: 13.00.04 / Luhanskyj nacionalnyj universytet im. T. Shevchenka, Luhansk, 2009. $312 \mathrm{~s}$.

Majyer N. V. Koncepciya formuvannya metodychnoyi kompetentnosti u majbutnix vykladachiv inozemnyx mov u procesi samostijnoyi roboty. Inozemni movy. 2016. №4 (88). S. 20-28

Надійшла до редколегії 17.05.21

Наталія Павлова, канд. пед. наук, доц.

Рівненський державний гуманітарний університет, Рівне, Україна

\section{ЦІЛЕСПРЯМОВАНИЙ ПІДХІД У СИСТЕМІ МЕТОДИЧНОЇ ПІДГОТОВКИ ВЧИТЕЛІВ ІНФОРМАТИКИ}

Проаналізовано класифікації педагогічних задач, які описують і проєктують професійну діяльність вчителя. Педагогічні задачі застосовують на всіх етапах здобуття студентами кваліфікації "вчитель", але з різною метою та в певних дидактичних умовах навчання. Виділено методичну задачу, у якій змодельовано педагогічну ситуачію у площині вивчення навчального предмета в закладі загальної середньої освіти і яка містить вимоги до осмислення і практичного використання вчителем загально-наукових, предметних психолого-педагогічних знань та вмінь, а також обізнаності з методикою навчання предмета. Обґрунтовано доцільність професійної підготовки майбутніх учителів з використанням навчально-методичних задач, призначеної для навчання студентів і формування методичної компетентності, зокрема вироблення нових особистісно вагомих методичних знань у вигляді понять і способів діяльності. Визначено, що задачі спонукають студентів усвідомлювати значимість знань, перетворювати і синтезувати їх, формувати виважені педагогічні рішення, планувати діяльність та прогнозувати наслідки їі виконання. Задля оволодіння загальною $і$ спеціальною методи кою навчання інформатики запропоновано розв'язувати аналітичні, конструктивні, творчі, рефлексивні навчально-методичні задачі. Навчально-методичні задачі, класифікують за різними критеріями, серед яких: специфіка змісту навчального матеріалу; спосіб досяанення результату; складність розв'язання. Процес розв'язання задач має свої особливості і складається з етапів: аналіз умови; мобілізація необхідних знань і досвіду для визначення шляхів та способів розв'язання; вибір найефективнішого способу розв'язання та його реалізація; аналіз процесу розв'язання задачі та одержаних результатів з боку викладача і студентів. Навчально-методичні задачі, поєднуючи процес навчання студентів і майбутню педагогічну діяльність, виконують мотиваційну, навчальну, діагностичну та розвиваючу функції. Навчально-професійний напрям, з одного боку, творчість та самостійність з іншого, дозволяють розглядати задачний підхід водночас як метод і як засіб колективного, групового та індивідуального навчання студентів у системі методичної підготовки в закладі вищої освіти.

Ключові слова: вчитель інформатики, здобувач освіти, навчально-методична задача. 